\title{
The Development and Implementation of Innovative Learning Resource with Guided Projects for the Teaching of Carboxylic Acid Topic
}

\author{
Jamalum Purba ${ }^{1}$, Manihar Situmorang $^{2, *}$, Ramlan Silaban' \\ ${ }^{1}$ Department of Chemistry Education, Graduate Study Program, Universitas Negeri Medan (State University of Medan), Medan, North \\ Sumatra, INDONESIA. \\ 2Department of Chemistry, Faculty of Mathematics and Naturas Science, Universitas Negeri Medan (State University of Medan), \\ Medan, North Sumatra, INDONESIA.
}

\begin{abstract}
Background: The development of good learning resources in line with current technology to facilitate active learning has become a trend in education. An innovative learning material is believed to be able to motivate the students to learn and to improving students' skills for chemistry and pharmacy students to handle chemical reaction. Objectives: The study aimed to enact an innovative learning material with guided project to be implemented as learning resources to improve student's performance in organic chemistry. Materials and Methods: This study was carried out at Universitas Negeri Medan with the involvement of 180 chemistry students in the Department of Chemistry. It consisted of the development and standardization of an innovative learning package with guided project and implementing it for the teaching of carboxylic acid topic. Results and Conclusion: An innovative learning package with project contextual example related to carboxylic acid topic has been developed in a systematic order and the projects were provided to guide the students to become independent learners. The learning package was easy to follow and guided the students to do scientific investigations. The guide projects integrated in the learning package facilitated the students to gain deeper understanding of organic chemistry concept, be able to set their own project to keep the students engage in curiosity and problem solving and develop students' skills on planning, actions and reporting the project results. The developed learning material is very effective to improve students' competence, where students' performance in experimental class $(M=83.23 \pm 4.41)$ was higher than that in control class $(M=77.22 \pm 4.79)$. Students' learning style has been changed to become independent learner.
\end{abstract}

Key words: Innovative learning resource, Guided project, Independent learner, Chemistry teaching, Students' performance.

\section{INTRODUCTION}

The massive change in the information technology has become a challenge in education system where teaching and learning instructional have to be adjusted with current technology to maximize students' participation in learning activities. The adaptation of technology in the teaching and learning process has brought a new learning environment that can enhance students' interest in the subject they learn. The lecture notes provided by lectures may not be sufficient to improve student's competence. ${ }^{1}$ The need for learning resources that are in line with current technology is very crucial since the students nowadays often choose their learning material that suits to their need. The students need to be facilitated with innovative learning material to provide contextual investigations that can promote critical thinking to improve academic performance. Innovative learning resources with guided project become an alternative to facilitate
Submission Date: 25-02-2019; Revision Date: 13-06-2019; Accepted Date: 17-07-2019

DOI: 10.5530/ijper.53.4.121 Correspondence: Prof. Dr. Manihar Situmorang, M.Sc., Ph.D, Department of Chemistry, Faculty of Mathematics and Naturas Science, Universitas Negeri Medan JI. Willem Iskandar, Medan, North Sumatra-20221, INDONESIA. Phone: 062-61-6613365 E-mail: msitumorang@ unimed.ac.id 
the students to engage in curiosity and problem solving to obtain a deep understanding on the subjects they learn. Furthermore, conducting a project is good strategy to to achieve the competencies for chemistry and pharmacy students.

The development of an innovative learning resource with guided project is a strategy to design a learning instruction that can connect the theory with real world to get the students engaged in their learning activities. ${ }^{2-5}$ The contents in innovative learning materials are the combination of contents of topics with practical examples and the strategy on contents delivery. ${ }^{6}$ An innovative learning resource with guided project is a strategy to do investigation via small research that can transform learning activity into learning opportunities to solve the given problems. The project is designed systematically to develop the knowledge and skills on specific affective target. ${ }^{7}$ The project based learning can be carried out through the project in the laboratory, field study, problem solving and assignments completion. ${ }^{8-10}$ The project required the students to master skills to manage learning activities starting from planning, actions and reporting the results. ${ }^{11}$ Through the project, the students are free to carry out independent learning activities to explore the finding in related to the current theory. ${ }^{12}$ The study would be very effective and efficient when the project has been prepared based on the goal target. ${ }^{13}$

Innovations in teaching and learning activities adjusted with current technology development have become the trend nowadays that can be implemented through teaching model, methods and strategy. ${ }^{14}$ An innovation is designed to attract students' interest to achieve learning goal. Learning innovation have been implemented via inquiry-based learning, project-based learning, ${ }^{15,16}$ and media and multimedia based. ${ }^{17,18}$ Innovation was done to provide the students with alternative learning resources to optimize the teaching and learning process, to provide more enjoyable learning environments and to improve learning motivation. ${ }^{19}$ One of the learning innovations that attract the attention is by enacting the guided project in the teaching Organic chemistry. A guided project is a semi-independent project that can facilitate learners to work systematically that is adjusted suited to their own learning style. The projects are integrated in the learning resources with the aim to strengthen the students with adequate knowledge and skills through implementation of the theory in to practice with contextual example. The guided project is believed to be able to motivate the students in the learning process as well as to maximize students' involvement in learning activity. Learning via projects, in addition to the regular lecture in the class, makes the students independent learners. Guided project is believed be able to bring the students to enjoy selflearning.

Organic chemistry is a compulsory course at the university curriculum aimed to develop the knowledge and skills in chemistry. ${ }^{20,21}$ Basic organic chemistry topics at university level have to be taught clearly in the principles of the theory and methods. Therefore, the subject has to be taught in a manner that attracts students' motivation to learn to accomplish their scientific competence. Carboxylic acid and its derivatives are a very important topic for undergraduate students that can be taught via project. The topic consisted of introduction to carboxylic acid and its derivatives, preparation of carboxylic acids, reactions of carboxylic acids, reduction of carboxylic acids and acid derivatives, quantitative relationships involving carboxylic acids. ${ }^{22}$ The project is designed to develop the skills in handling chemistry reaction, synthesis with calculation of starting material and the yield quantitatively. Therefore, it is important for educator to develop an innovative learning resource that reflect on the current technology development to provide a better understanding on the subject they learn. The aim of this study is to develop a chemistry learning resource with guided project to be used as a learning media on the teaching of Carboxylic acid. The strategy is made to enrich chemistry topics with contextual examples by integrating relevant projects to provide a standard learning material for science major for university students. The learning material is arranged systematically containing rich chemistry contents, learning activities and the assessments aligned to the learning outcome. Implementation of the developed material to improve students' performances has become a main target in this study. The contribution of the learning material to motivate the students to actively engage in learning and constructing the knowledge and skills are also investigated.

\section{MATERIALS AND METHODS \\ Population and Sample}

The study was carried out in the Department of Chemistry, Faculty of Mathematic and Natural Science, Universitas Negeri Medan, in academic year 2017/2018 with involvement of 180 chemistry students and 9 lecturers experienced in teaching Organic chemistry. The sample are divided into two groups, namely experimental class and control class. The distributions of population and samples involved in the study are presented in Table 1. All samples are homogenized from their performance in preliminary test, where the samples with 


\begin{tabular}{|c|c|c|c|c|c|c|c|}
\hline \multirow[t]{2}{*}{ No } & \multirow[t]{2}{*}{ Study Program } & \multirow{2}{*}{$\begin{array}{l}\text { Number of } \\
\text { students }\end{array}$} & \multirow{2}{*}{$\begin{array}{l}\text { Number of } \\
\text { parallel class }\end{array}$} & \multicolumn{2}{|c|}{ Selected sample* } & \multirow{2}{*}{$\begin{array}{l}\text { Total } \\
\text { sample }\end{array}$} & \multirow{2}{*}{$\begin{array}{l}\text { Short description of the Study } \\
\text { Program }\end{array}$} \\
\hline & & & & Exp. & Ctrl. & & \\
\hline 1 & Chemistry Education & 200 & 4 & 60 & 60 & 120 & - Major in Chemistry education \\
\hline 2 & Chemistry & 76 & 2 & 30 & 30 & 60 & - Major in Chemistry \\
\hline & Total & 276 & 6 & 90 & 90 & 180 & \\
\hline
\end{tabular}

*Exp. is the students in experimental class that were treated with given an innovative learning material with guided project and Ctrl. are the students in control class that were treated with existing Organic chemistry textbook

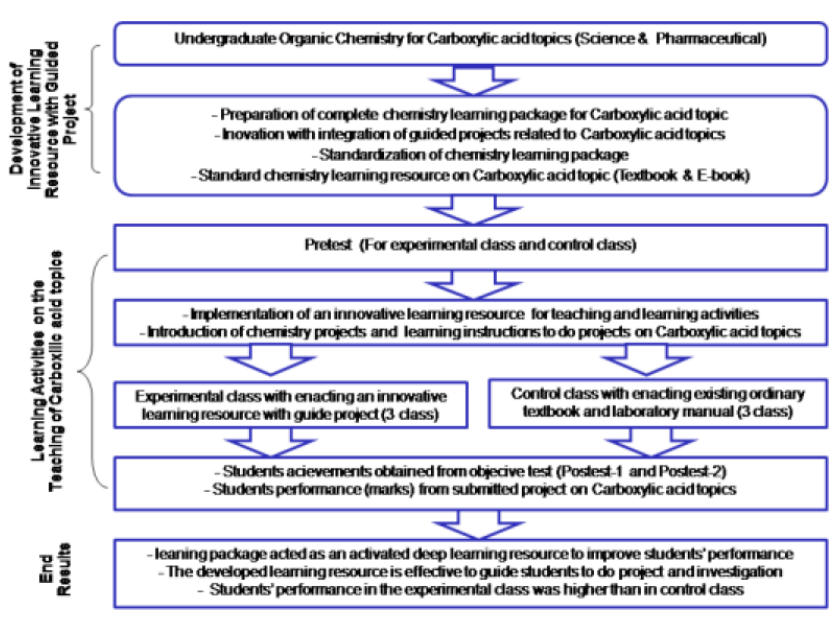

Figure 1: The overview of research procedures in the development of innovative learning resource with guided project and its implementation for the teaching of Carboxylic acid topics.

relatively having similar achievement are included in the data analysis while the outlier samples are excluded.

\section{Research Procedures}

The research procedure consisted of the development and standardization of an innovative learning package with projects on Carboxylic acid topic that met the requirement as stated in the university curriculum. A developed standard innovative chemistry learning material with guided project is then implemented in teaching and learning activities for experimental class and the existing textbooks are used in control class. ${ }^{23}$ The research procedures are summarized in Figure 1.

\section{Development of Innovative Learning Resources with Guided Project}

The development of learning resource with project is conducted starting from the analysis of Organic chemistry textbooks on Carboxylic acid topics to obtain relevant chemistry subjects to be included in learning materials for undergraduate science students suited to the university curriculum ${ }^{24}$ following the procedures explained previously. ${ }^{25}$ A package of learning material containing project on Carboxylic acid topics was prepared with adjustment to local contents and the availability of chemicals and equipments in the laboratory. ${ }^{26,27}$ The learning package was then evaluated for its contents by experienced lecturers. The feasibility of developed material was also assessed by senior students that have studied the subject of Organic chemistry in previous year. It is then standardized for its performance based on the criteria given by Indonesian National Education Standards Board (BSNP). A set of innovative learning material was then provided both in printed and electronic versions.

\section{Preparation of Research Instruments}

The instruments used in this study are similar to those explained in the previous study. ${ }^{25,28}$ They consisted of a package of developed innovative learning resource with guided project for Carboxylic acid, sets of standard questionnaires and evaluation tests (pre-test, post-test 1 and post-test 2). The standard evaluation tests (20 Problems) are provided in multiple choice tests to measure students' achievement covering Carboxylic acid topics.

\section{Teaching and Learning Activities and Data Collection}

Implementation of innovative learning resource with project is carried out for teaching of Carboxylic acid topics. Before teaching and learning activities are carried out, the lecturers are trained to explain their involvement in the study to select the sample, to teach students as listed in a lesson plan, to use the developed learning package, to instruct the students to do project, to motivate the students to use university facilities for self learning, to perform evaluations (pre-test and post-test) and to collect data (marking the submitted projects reports). Preliminary evaluation was performed to investigate how far the students knew the subject of Carboxylic acid topics to be taught. The teaching and learning activities are carried out to experimental classes by using the developed learning resources, while the students in control class are taught by using existing organic chemistry textbook. The allocated time in lecture was similar and the other factors were maintained the same in both classes. The evaluation test (post-test 1) 
was carried out after the completion of all materials and the projects on Carboxylic acid topics, where post-test 2 was given a month after finishing post-test 1 . The score for evaluation test was obtained from the right answers of multiple-choice test with penalty applied for any wrong answers, followed by converting the score to a 0 to 100 scale.

There are five sets of compulsory projects to be completed during the allocated timetable which are chosen from available ten projects in the learning package. The marks for the submitted projects are from three parts, the contents of the project, the precision value to the target products and the reports. The contents are evaluated from how deep the students is able to construct the projects starting from planning, laboratory activities, record keeping and washing up apparatus. The yield target value is marked from how close recovery of product yield is obtained in the project compared to the true value of target compounds in the given samples. The reports are assessed from report format, which includes font, margin, layout, presentation of figure and table, style, coherency and submission deadline. The score for projects is the average from five submitted projects with marking scale of $0-100$.

\section{RESULTS AND DISCUSSION}

\section{Innovative Learning Resource with Guided Project}

The development of innovative learning resource with guided project for Carboxylic acid topic is made following the success in previous study. ${ }^{14,22,25}$ Various Organic chemistry textbooks are used as sources to construct the learning material on Carboxylic acid topics that are suited to university curriculum. ${ }^{29-31} \mathrm{~A}$ draft of chemistry material is prepared rich in scientific content accompanied with local contents for project based learning and hyperlinked to trusted websites for future reading. The chemistry topic and the type of innovation that have been integrated into the learning resource is summarized in Table 2.

\section{Standardization of Learning Material}

To ensure the requirements for learning material by BSNP criteria has been met, the developed learning material is standardized followed the procedures explained in previous study, ${ }^{25}$ and the results are listed in Table 3. The respondents considered that high quality teaching and learning resource has been provided $(\mathrm{M}=3.79 \pm 0.40)$. The chemistry material and the components that are integrated in the learning package have meet the requirement for learning resource criteria. The lecturer gave positive comments to express the content of Carboxylic acids topic in the learning material suited to the need for undergraduate students.

\section{Implementation of Learning Material on Teaching and Learning Activities}

The students in experimental and control class were then treated differently in the teaching of Carboxylic acid topic. The students in experimental class are given a set of standard innovative learning material on Carboxylic acid topic. The learning resource was facilitated with examples of projects along with the instruction to do similar projects related to subtopic of Carboxylic acid that are being taught. The students in experimental class are required to submit the complete reports of five sets of projects, those are to be chosen from available nine projects that are provided in the developed learning package on Carboxylic acid topic. The other group of control class was also given the same topic with laboratory experiments along with separate instruction of laboratory manual on Carboxylic acid topic, those are the Organic chemistry laboratory manual that has been used in the previous year. Soft copy of Organic chemistry textbooks is also given to students in both class as supplements, however, the students are also suggested to search and chose relevant learning materials of Organic textbooks containing Carboxylic acid topic in the university library.

The students' basic knowledge on Carboxylic acids topic is assessed through pre-test as summarized in Table 4. Screening for outlier samples has been made from students' scores in pre-test and only homogenic sample are included in the data analysis. Students' achievements from pre-test are tend to be similar in experimental class $(\mathrm{M}=20.17 \pm 4.61)$ and control class $(\mathrm{M}=20.28 \pm 4.15)$, where both groups are statistically not different. It can be said the starting knowledge of the students on the Carboxylic acid topics in both groups before commencing the learning activities are assigned to be very low (see students score on pretest in Table 4).

\section{Students' Performances after Completing the Projects}

The students have completed the required compulsory five projects on Carboxylic acid topic and the submitted reports have been marked based on their investigations. The marking system have been adjusted to the chosen projects with the intention to see students' skills and competence that have been achieved from projects activities in the laboratory. Innovative learning resources has influenced the students' learning style in experimental class. They tend to focus on doing the project 
Table 2: Description of chemistry contents of Organic chemistry for Carboxylic acid topics and the innovations have been made into the chemistry learning resource.

\begin{tabular}{|c|c|c|c|}
\hline No & Chemistry Topics & $\begin{array}{l}\text { The descriptions of innovation that has been made into chemistry } \\
\text { learning materials for Carboxylic acid topics }\end{array}$ & Guided Project \\
\hline 1. & $\begin{array}{l}\text { Introduction to } \\
\text { Carboxylic Acid and } \\
\text { its Derivatives }\end{array}$ & $\begin{array}{l}\text { Introduction to Carboxylic acid and its derivatives consisted of the } \\
\text { subtopics of Nomenclature of carboxylic acids, Structure and bonding } \\
\text { of carboxylic acid, Naming carboxylic acid salts and Acidity of carboxylic } \\
\text { acids. The learning materials are equipped with model structures and a } \\
\text { hyperlink to trusted and relevant websites for future reading. The drills and } \\
\text { project to construct the structure of carboxylic acids compounds, including } \\
\text { carboxylic acid salts and acidity of carboxylic acids. Evaluation test related } \\
\text { to carboxylic acid and its derivatives was also prepared. }\end{array}$ & $\begin{array}{l}\text { Project } 1 \text { was using } \\
\text { media of molimod to } \\
\text { illustrate carboxylic acid } \\
\text { and its derivatives. }\end{array}$ \\
\hline 2. & $\begin{array}{l}\text { Preparation of } \\
\text { Carboxylic Acids }\end{array}$ & $\begin{array}{l}\text { The sub topic of preparation of carboxylic are the oxidation of alkenes, } \\
\text { Ozonolysis of alkenes, the oxidation of primary alcohols and aldehydes, } \\
\text { the oxidation of alkyl benzenes, Hydrolysis of nitriles, the carbonation of } \\
\text { Grignard reagents, Synthesis of substituted acetic acids via acetoacetic } \\
\text { ester, Synthesis of substituted acetic acid via malonic ester, á-halo acids, } \\
\text { á-hydroxy acids and á, } \beta \text {-unsaturated acids. The techniques to prepare } \\
\text { carboxylic acids from different starting material were demonstrated by } \\
\text { using video and multimedia. A hyperlink to trusted and relevant websites } \\
\text { for future reading has been given. The instructions to do project similar to } \\
\text { the given examples were integrated. The example of problems and the } \\
\text { evaluation test related to preparation of carboxylic acids was also included. }\end{array}$ & $\begin{array}{l}\text { Project } 2 \text { and } 3 \text { are } \\
\text { the preparations of } \\
\text { carboxylic acid through } \\
\text { oxidation and reduction } \\
\text { reactions. }\end{array}$ \\
\hline 3. & $\begin{array}{l}\text { Reactions of } \\
\text { Carboxylic Acids }\end{array}$ & $\begin{array}{l}\text { Specific topics on reactions of carboxylic acids were provided with } \\
\text { contextual examples. The reaction of Carboxylic acids was provided } \\
\text { through Ester formation, Nonreversible ester formation, Methyl ester } \\
\text { formation, Amide formation, Acid halide formation, Acid anhydride } \\
\text { formation, Decarboxylation reaction, Hunsdiecker reaction and Kolbe } \\
\text { electrolysis. Sets of mini projects have been provided on reactions of } \\
\text { carboxylic acids. The material was also equipped with a short video on how } \\
\text { the reactions of carboxylic acids be proceeded. The problem examples and } \\
\text { the evaluation tests on reactions of carboxylic acids were also given. }\end{array}$ & $\begin{array}{l}\text { Project } 4-5 \text { are the } \\
\text { reaction of carboxylic } \\
\text { acids through ester } \\
\text { formation or methyl } \\
\text { ester formation. }\end{array}$ \\
\hline 4. & $\begin{array}{l}\text { Reduction of } \\
\text { Carboxylic } \\
\text { Acids and Acid } \\
\text { Derivatives }\end{array}$ & $\begin{array}{l}\text { Subtopic on the reduction of carboxylic acids and acid derivatives are } \\
\text { arranged with reductions of carboxylic acid derivatives, reduction of esters, } \\
\text { reduction of acid halides, reduction of amides, reactions of carboxylic acid } \\
\text { derivatives and the reactivity of carboxylic acid derivatives. The technique } \\
\text { was focused to equip the students with the skills on handling reduction } \\
\text { reaction. The project examples on the reduction reaction are provided. It } \\
\text { was also equipped with example problem and solution, the evaluation test } \\
\text { and hyperlinks to relevant websites as comparison and future reading. }\end{array}$ & $\begin{array}{l}\text { Project 6-7 are reduction } \\
\text { of carboxylic acids and } \\
\text { acid derivatives. }\end{array}$ \\
\hline 5 & \begin{tabular}{|l} 
Quantitative \\
Relationships \\
Involving \\
Carboxylic Acids
\end{tabular} & $\begin{array}{l}\text { The quantitative relationships involving carboxylic acids are provided, } \\
\text { mainly on the synthesis with calculation of starting material and the yield } \\
\text { quantitatively. Those are including the synthesis of carboxylic acids by the } \\
\text { carboxylation of Grignard reagents, the synthesis of carboxylic acids by } \\
\text { the preparation and hydrolysis of nitriles, halogenation of carboxylic acids } \\
\text { (Hell-Volhard-Zelinsky Reaction) and spectroscopic analysis of carboxylic } \\
\text { acids. The calculation composition of the product and the problem } \\
\text { examples were also included. The use of spread sheet to determine the } \\
\text { composition percentage of the compounds was also introduced. }\end{array}$ & $\begin{array}{l}\text { Project } 8-10 \text { are } \\
\text { synthesis of carboxylic } \\
\text { acids, purification } \\
\text { technique and } \\
\text { calculation of yield. }\end{array}$ \\
\hline
\end{tabular}

by looking and imitating the project examples available in the developed learning material. The students in experimental class are enthusiastic to use the developed material when learning about the Carboxylic acid topic. The complete and systematic structure of the learning material along with the availability of hyperlink of trusted websites that are provided in the learning package are found very helpful to guide the students to learn Carboxylic acid topic. The students are able to do observation and collect the data for their report on the assigned project. Students' marks that are obtained from portfolio of submitted projects are summarized in Table 5 . The results showed that learning material containing guided projects influence students' knowledge on organic chemistry. The student's ability to complete and to report the projects are found different in experimental class compared to the of laporatory reports in control class (see data in Table 5).

The students in experimental class are able to complete the projects in their learning timetable. The students' 


\begin{tabular}{|c|c|c|c|c|}
\hline \multirow{2}{*}{$\begin{array}{l}\text { Book } \\
\text { components }\end{array}$} & \multirow{2}{*}{$\begin{array}{l}\text { Short description of innovative learning resource with guided } \\
\text { project }\end{array}$} & \multicolumn{3}{|c|}{ Respondents opinion $(M \pm S D)$} \\
\hline & & $L(n=9)$ & $S(n=58)$ & Average \\
\hline \multirow[t]{2}{*}{ Content } & $\begin{array}{l}\text { - The completeness of Chemistry contents on Carboxylic acid } \\
\text { suited to Organic chemistry curriculum for undergraduate chemistry } \\
\text { and pharmacy }\end{array}$ & $3.67 \pm 0.50$ & $3.83 \pm 0.38$ & $3.75 \pm 0.44$ \\
\hline & $\begin{array}{l}\text { - The accuracy of the contents of the learning material with project } \\
\text { on Carboxylic acid topic }\end{array}$ & $3.67 \pm 0.50$ & $3.86 \pm 0.35$ & $3.77 \pm 0.42$ \\
\hline \multirow[t]{2}{*}{ Extension } & $\begin{array}{l}\text { - Presented the learning material with project by the integration } \\
\text { of local contents, laboratory experiment, contextual application, } \\
\text { learning media and the learning strategy in the learning package }\end{array}$ & $3.67 \pm 0.50$ & $3.81 \pm 0.39$ & $3.74 \pm 0.45$ \\
\hline & $\begin{array}{l}\text { - The Organic chemistry contents and the projects are clearly } \\
\text { derived on Carboxylic acid topic }\end{array}$ & $3.89 \pm 0.33$ & $3.92 \pm 0.28$ & $3.90 \pm 0.31$ \\
\hline \multirow[t]{2}{*}{ Depth } & $\begin{array}{l}\text { - The contents of Carboxylic acid topic are presented in good order: } \\
\text { introduction, main concepts, problem example, guided projects, } \\
\text { drills, quiz and the hyperlinks to trustworthy websites }\end{array}$ & $3.67 \pm 0.50$ & $3.86 \pm 0.35$ & $3.77 \pm 0.42$ \\
\hline & - Application of Carboxylic acid topic in real life & $3.89 \pm 0.33$ & $3.85 \pm 0.36$ & $3.87 \pm 0.35$ \\
\hline \multirow{3}{*}{ Design } & $\begin{array}{l}\text { - The design of learning material is suitable between the layout with } \\
\text { the target material of Carboxylic acid }\end{array}$ & $3.67 \pm 0.50$ & $3.85 \pm 0.36$ & $3.760 .43 \pm$ \\
\hline & $\begin{array}{l}\text { - Presentation of the illustrations, figures, table and images are } \\
\text { adequate to Organic chemistry contents }\end{array}$ & $3.67 \pm 0.50$ & $3.90 \pm 0.30$ & $3.78 \pm 0.40$ \\
\hline & - Involving learners for interactive study & $3.89 \pm 0.33$ & $3.83 \pm 0.38$ & $3.86 \pm 0.36$ \\
\hline \multirow{4}{*}{ Language } & - In accordance with the development of learner & $3.67 \pm 0.50$ & $3.85 \pm 0.36$ & $3.76 \pm 0.43$ \\
\hline & $\begin{array}{l}\text { - The chemistry material and the projects are easy to read, the } \\
\text { language is simple and provides communicative message to } \\
\text { readers }\end{array}$ & $3.78 \pm 0.44$ & $3.81 \pm 0.39$ & $3.80 \pm 0.42$ \\
\hline & $\begin{array}{l}\text { - The presentation and scientific messages are straightforward, } \\
\text { having accurate on the typist of chemical structure, reaction and } \\
\text { symbol }\end{array}$ & $3.67 \pm 0.50$ & $3.86 \pm 0.35$ & $3.77 \pm 0.42$ \\
\hline & Average & $3.73 \pm 0.45$ & $3.85 \pm 0.35$ & $3.79 \pm 0.40$ \\
\hline
\end{tabular}

Table 4: Students' starting knowledge on Carboxylic acid topic based on their achievements on pre-test.

\begin{tabular}{|c|c|c|c|c|c|c|c|c|}
\hline \multirow{3}{*}{$\begin{array}{c}\text { Evaluation } \\
\text { Test }\end{array}$} & \multicolumn{4}{|c|}{ Students' achievements counted as the average score $(M \pm S D)$ on Chemistry evaluation test } \\
\cline { 2 - 9 } & $\boldsymbol{A}(\boldsymbol{n}=\mathbf{3 0})$ & $\boldsymbol{C}(\boldsymbol{n}=\mathbf{3 0})$ & $\boldsymbol{E}(\boldsymbol{n}=\mathbf{3 0})$ & Average & $\boldsymbol{B}(\boldsymbol{n}=\mathbf{3 0})$ & $\boldsymbol{D}(\boldsymbol{n}=\mathbf{3 0})$ & $\boldsymbol{F}(\boldsymbol{n}=\mathbf{3 0})$ & Average \\
\cline { 2 - 10 } & $20.33 \pm 6.01$ & $20.67 \pm 3.41$ & $19.50 \pm 4.42$ & $20.17 \pm 4.61$ & $20.33 \pm 4.14$ & $20.83 \pm 4.17$ & $19.67 \pm 4.14$ & $20.28 \pm 4.15$ \\
\hline
\end{tabular}

*The learning effectiveness is calculated by comparing post-test 2 with post-test $1 . A=C$ Chemistry Education students in regular $A$ class; $B=C$ hemistry Education students in regular $\mathrm{B}$ class; and $\mathrm{C}=$ Chemistry Education students in regular $\mathrm{C}$ class; $\mathrm{D}=$ Chemistry Education students in non-regular class; $\mathrm{E}=\mathrm{Chemistry}$ students in regular $\mathrm{A}$ class; and $\mathrm{F}=$ Chemistry students in regular $\mathrm{B}$ class.

\section{Table 5: Students performances obtained from five submitted projects portfolio on Carboxylic acid.}

\begin{tabular}{|c|c|c|c|c|c|c|c|c|}
\hline \multirow{3}{*}{$\begin{array}{c}\text { Submitted } \\
\text { Projects }\end{array}$} & \multicolumn{8}{|c|}{ Students' marks counted as the average score $(M \pm S D)$ on reports portfolio } \\
\hline & \multicolumn{4}{|c|}{ Project reports of Experimental Class } & \multicolumn{4}{|c|}{ Laboratory reports of Control Class } \\
\hline & $A(n=30)$ & $C(n=30)$ & $E(n=30)$ & Average & $B(n=30)$ & $D(n=30)$ & $F(n=30)$ & Average \\
\hline Project 1 & $80.27 \pm 5.53$ & $83.43 \pm 3.98$ & $78.40 \pm 6.61$ & $80.70 \pm 5.37$ & $75.97 \pm 6.96$ & $70.17 \pm 6.75$ & $73.90 \pm 7.19$ & $73.34 \pm 6.97$ \\
\hline Project 2 & $84.43 \pm 5.46$ & $85.90 \pm 4.52$ & $81.70 \pm 7.28$ & $84.01 \pm 5.75$ & $77.00 \pm 6.02$ & $78.47 \pm 4.44$ & $77.07 \pm 5.67$ & $77.51 \pm 5.38$ \\
\hline Project 3 & $83.00 \pm 5.08$ & $85.73 \pm 5.15$ & $83.00 \pm 5.88$ & $83.91 \pm 5.37$ & $80.90 \pm 7.46$ & $80.27 \pm 5.42$ & $81.23 \pm 5.69$ & $80.80 \pm 6.19$ \\
\hline Project 4 & $83.00 \pm 5.08$ & $85.73 \pm 5.15$ & $83.00 \pm 5.88$ & $83.91 \pm 5.37$ & $80.90 \pm 7.46$ & $80.27 \pm 5.42$ & $81.23 \pm 5.69$ & $80.80 \pm 6.19$ \\
\hline Project 5 & $83.00 \pm 5.08$ & $85.73 \pm 5.15$ & $83.00 \pm 5.88$ & $83.91 \pm 5.37$ & $80.90 \pm 7.46$ & $80.27 \pm 5.42$ & $81.23 \pm 5.69$ & $80.80 \pm 6.19$ \\
\hline Average & $83.64 \pm 4.44$ & $85.02 \pm 3.16$ & $81.03 \pm 5.62$ & $83.23 \pm 4.41$ & $77.96 \pm 4.41$ & $76.30 \pm 4.38$ & $77.40 \pm 5.58$ & $77.22 \pm 4.79$ \\
\hline
\end{tabular}

$\mathrm{A}=$ Chemistry Education students in regular A class; B = Chemistry Education students in regular B class; and C = Chemistry Education students in regular C class; $\mathrm{D}=$ Chemistry Education students in non-regular class; $\mathrm{E}=$ Chemistry students in regular $\mathrm{A}$ class; and $\mathrm{F}=$ Chemistry students in regular $\mathrm{B}$ class 
performance obtained from submitted projects in experimental class $(\mathrm{M}=83.23 \pm 4.41)$ is higher than in control class $(\mathrm{M}=77.22 \pm 4.79)$. The results confirmed that the use of learning material with guided projects is able to help the students to set the target projects. The examples that are provided in the learning material serve to direct students to do organic activities correctly. In accordance to the students' mark on their submitted project reports, the students in experimental class have also showed high motivation to complete the projects and have confidence to complete the challenge that have been targeted in the laboratory works. The presence of project examples that are integrated in an innovative learning material improve curiosity, engagement, attention and results in high satisfaction on the chemistry skills dealing with project management. The facilities that are integrated in the learning material help the students to continue to study chemistry until the required competencies have been achieved.

After completing the teaching and learning activities on Carboxylic acid topic, the post-test 1 is conducted to both groups. The students' achievement results from post-test 1 are summarized in Table 6 . The results showed that students' achievement in experimental class $(M=77.17 \pm 5.03)$ is found higher than that in the control class $(M=69.94 \pm 5.43)$. The effectivity of learning resources to extend students retention knowledge on Carboxylic acid topic has been examined in post-test 2 (Table 6). The results showed that students' achievement in experimental class $(\mathrm{M}=82.11 \pm 5.66)$ is higher than that in control class $(M=65.39 \pm 5.16)$. For experimental class, the students' achievements in post-test 2 improved compared to their achievement in post-test 1 , where the decline trend is observed in control class (see results in Table 6). The results have showed that the effectiveness of the developed learning resource to extend knowledge retention in experimental class
$(105 \%)$ is higher than the ordinary teaching with laboratory manual $(93 \%)$ and innovative learning resource has significantly proven to be able to improve student's achievement in Organic chemistry. The developed learning material with guided projects was adequate to be used as a learning resource in the teaching and learning activities. The students in experimental class was observed to participate actively in their learning process starting from planning, action to complete their projects and to write and submitted project reports.

\section{DISCUSSION}

A package of good quality and standard learning resource with complete information on the topic of Carboxylic acid has been properly developed and intensively used in the teaching and learning activities on experimental class. Sets of projects on Carboxylic acids topic have been integrated in the learning material to facilitate the students with simple procedures and complex practical works and all of them are designed with full consideration on laboratory safety. The learning package, both printed and electronic materials have been prepared as a learning media in the class. ${ }^{27}$ An innovative learning resource developed in this study can be used as a model of practical guide for scientists of chemists, pharmacologists, biochemists or practitions on the use of guide projects to study undergraduate Organic chemistry. ${ }^{32}$ Implementation of the learning resource with guided projects has been proven to be very helpful to guide the students to learn Organic chemistry through projects. The chemistry contents in the developed learning resource has been proven to be very useful for the students to obtain complete information and knowledge on Carboxylic acid topic. The designed projects that are integrated in the learning material are found very effective to guide unskilled students to perform chemistry project as a strategy to achieve their competencies and to

\begin{tabular}{|c|c|c|c|c|c|c|c|c|}
\hline \multirow{3}{*}{$\begin{array}{c}\text { Evaluation } \\
\text { Test }\end{array}$} & \multicolumn{8}{|c|}{ Students' achievements counted as the average score $(M \pm S D)$ on Chemistry evaluation test } \\
\hline & \multicolumn{4}{|c|}{ Experimental Class } & \multicolumn{4}{|c|}{ Control Class } \\
\hline & $\mathbf{A}(n=30)$ & C $(n=30)$ & $\mathrm{E}(n=30)$ & Average & $\mathrm{B}(n=30)$ & $\mathbf{D}(n=30)$ & $\mathbf{F}(n=30)$ & Average \\
\hline Post-test 1 & $78.50 \pm 6.45$ & $78.00 \pm 4.66$ & $77.17 \pm 5.03$ & $77.89 \pm 5.38$ & $70.17 \pm 5.33$ & $68.33 \pm 4.79$ & $71.33 \pm 6.15$ & $69.94 \pm 5.43$ \\
\hline Post-test 2 & $82.17 \pm 6.39$ & $82.50 \pm 4.10$ & $81.67 \pm 6.48$ & $82.11 \pm 5.66$ & $65.67 \pm 5.37$ & $62.50 \pm 4.31$ & $68.00 \pm 5.81$ & $65.39 \pm 5.16$ \\
\hline $\begin{array}{l}\text { Learning } \\
\text { Effectivity } \\
(\%)^{*}\end{array}$ & 105 & 106 & 106 & 105 & 94 & 91 & 95 & 93 \\
\hline
\end{tabular}

*The learning effectiveness is calculated by comparing post-test 2 with post-test $1 . \mathrm{A}=$ Chemistry Education students in regular $\mathrm{A}$ class; $\mathrm{B}=$ Chemistry Education students in regular B class; and $\mathrm{C}=$ Chemistry Education students in regular C class; $\mathrm{D}=$ Chemistry Education students in non-regular class; $\mathrm{E}=\mathrm{Chemistry} \mathrm{students}$ in regular $\mathrm{A}$ class; and $\mathrm{F}=$ Chemistry students in regular $\mathrm{B}$ class 
improve students scientific research skills. ${ }^{33,34}$ The availability of contextual project examples in the learning resource enables the students to deal with complicated chemistry reaction of Carboxylic acids through ester formation, amide formation, acid halide formation and another electrolysis strategy. ${ }^{35}$ The project examples are prepared to guide the students to have deeper thinking in the planning and implementing projects so that they engage and sustain in curiosity across the project to make the students learn more deeply, particularly to achieve advance skill on the synthesis and the calculation of starting material and the yield quantitatively. 36,37

It has been observed in the laboratory that the students in experimental class were conducting the projects very well, including in the chemical handling, collecting data and writing reports. Five projects reports have been submitted by the students and good marks are achieved (Table 6). The students have high score in the project reports because they knew the technique and the product target after reading the project examples in the learning material. However, most of students chose the project topic similar to the examples provided in the learning material. By completing the projects, they have mastered various skills as a way to prepare themselves for careers and future life challenges. ${ }^{38}$ The students improve the ability in the academic communication skills, collaboration, creativity and critical thinking. 39,40 The developed learning resource has become an efficient tool to assist the students to learn and to facilitate learning activities to be more enjoyable. The skills on observing the chemical process, recording and collecting the data, analyzing and interpreting the results are also developed. ${ }^{41}$ The study on project based learning are proven to develop students' critical thinking and improve the knowledge and understanding on the topic that was being learned. ${ }^{42}$ Furthermore, collaborative learning style with independent process to engage with the problem-solving process have also been achieved. ${ }^{43,44}$ Students' achievement in post-test 1 is higher in experimental class compare to results in control class, both groups are significantly different. It is proved that the developed learning resource with guided project has a significant contribution to improve students' achievement in chemistry.

\section{CONCLUSION}

An innovative learning resource with guided project on the teaching of Organic chemistry for Carboxylic acid topic has been provided in a standard mode. It consisted of five sub chapters that are equipped with relevant contextual project examples, illustration with integration of learning media, the hyperlink to a trust website, problem solving and evaluation test. The design and contents of chemistry material has met the requirements for undergraduate chemistry and pharmacy resources. The students were enthusiastic to do the projects, completed and submitted the report correctly. The students' skills on dealing with specific chemical reaction for Carboxylic acid topic has been achieved. Implementation of innovative learning resource with guided project has proven to improve students' performance on Organic Chemistry. Students learning outcomes in experimental class is found higher than that obtained in control class. The developed learning resource is effective to facilitate active learning for students to do investigation that be able to improve students' performance in Organic chemistry.

\section{Financial Disclosure}

The authors acknowledge the support from Directorate Research and Community Service, Directorate General Strengthen Research and Development, Ministry of Research, Technology and Higher Education Republic of Indonesia, Financial Year 2018, Under Project Penelitian Strategis Nasional Institusi, Contract No. 027/UN33.8/LL/2018.

\section{ACKNOWLEDGEMENT}

The help from Lecturer in the Department of Chemistry, Faculty of Mathematics and Natural Sciences, Universitas Negeri Medan for their involvement in the study are gratefully acknowledged. The authors also acknowledge Isli Iriani Pane from the Language Centre of Universitas Negeri Medan who have helped in the English proofreading process.

\section{CONFLICT OF INTEREST}

The authors declare no conflict of interest.

\section{ABBREVIATIONS}

UNIMED: Universitas Negeri Medan; BSNP: Badan Standar Nasional Pendidikan (Indonesian National Education Standards Board); KKNI: Kerangka Kualifikasi Nasional Indonesia (Indonesian National Qualifications Framework).

\section{REFERENCES}

1. Gleadow R, Macfarlan B, Honeydew M. Design for learning-a case study of blended learning in a science unit. F1000Research. 2015;4:898-17. doi: 10.12688/f1000research.7032.2

2. Martalina DS, Situmorang M, Sudrajat A. The Development of Innovative Learning Material with Integration of Project and Multimedia for the Teaching of Gravimetry, Advances in Social Science. Education and Humanities Research, $3^{\text {rd }}$ Annual International Seminar on Transformative Education and Educational Leadership. 2018;200:735-40. 
3. Siew NM, Amir N, Chong CL, The perceptions of pre-service and in-service teachers regarding a project-based STEM approach to teaching science. Springerplus. 2015;4(1):8. (20 pages), http://www.springerplus.com/ content/4/1/8.

4. Sheng T, Hu Q. Human Extracellular Superoxide Dismutase Recombination: a Project Based Learning Program in Biochemistry Designed for Nursing Students. Asian J Nursing Edu and Research. 2012;2(3):135-9.

5. Atasoy BM, Sarikaya O, Kuscu MK, Yondem M, Buyukkara E, Eken EG. et al. Students Meeting with Caregivers of Cancer Patient: Results of an Experience-Based Learning Project. J Canc Educ. 2012;27(4):656-63. DOI 10.1007/s13187-012-0387-3.

6. Chilkoti G, Mohta M, Wadhwa R, Saxena AK. Problem-Based Learning Research in Anesthesia Teaching: Current Status and Future Perspective. Anesthesiol Res Pract. 2014. Article ID 263948, (7 pages), http://dx.doi. org/10.1155/2014/263948

7. Ellinas C, Allan N, Durugbo C, Johansson A. How Robust Is Your Project? From Local Failures to Global Catastrophes: A Complex Networks Approach to Project Systemic Risk. PLoS One. 2015;10(11):e0142469. DOI:10.1371/ journal.pone.0142469

8. Uskokovíc V. Major Challenges for the Modern Chemistry in Particular and Science in General. Found Sci. 2010;15(1):303-44.

9. Karimi R. Interface between problem-based learning and a learner-centered paradigm. Adv Med Educ Pract. 2011;2:117-25.

10. Azer SA, Hasanato R, Al-Nassar S, Somily A, AISaad MM. Introducing integrated laboratory classes in a PBL curriculum: Impact on student's learning and satisfaction. BMC Med Educ. 2013;13(1):71-83.

11. Laur D. Authentic Learning Experiences, A Real-World Approach to ProjectBased Learning. Eye On Education, Routledge, New York. 2013.

12. Adams S, DeCastro P, Echenique P, Estrada J, Hanwell MD, Murray-Rust P, et al. The Quixote project: Collaborative and Open Quantum Chemistry data management in the Internet age. J Cheminform. 2011;3(1):38. http://www. jcheminf.com/content/3/1/38.

13. Hughes L. Construction and Evaluation of an Online Microbiology Course for Nonscience Majors. J Microbiol Biol Educ. 2008;9(1):30-7.

14. Sinaga $M$, Situmorang $M$, Hutabarat $W$. Implementation of Innovative Learning Material to Improve Students Competence on Chemistry. Indian J Pharm Educ Res. 2019;53(1):28-41.

15. Petersen JC, Judge L, Pierce DA. Conducting a Community-based Experiential-Learning Project to Address Youth Fitness. J Phys Educ Recreat Dance. 2012;83(6):30-6.

16. Rhodes C, Garrick J. Project-based learning and the limits of corporate knowledge. J Manag Educ. 2003;27(4):447-71.

17. Sary SP, Situmorang M, Tarigan S. Development of Innovative Learning Material with Multimedia to Increase Student Achievement and Motivation in Teaching Acid Base Titration. Advances in Social Science. Education and Humanities Research, $3^{\text {rd }}$ Annual International Seminar on Transformative Education and Educational Leadership. 2018;200:422-5.

18. Noor MM, llias K. Practice Teaching and Learning Using Interactive Multimedia Innovation For Non-Optional Teachers Teaching In Music Educations. Academic Research International. 2013;4(2):338-46.

19. Lee PC, Lin CT, Kang HH. The influence of open innovative teaching approach toward student satisfaction: a case of Si-Men Primary School. Qual Quant. 2015;1-17.

20. Straumanis A. Organic Chemistry, A Guided Inquiry. $2^{\text {nd }}$ Ed. Houghton Mifflin Harcourt Publishing Co., Boston. 2009.

21. Ckrocker K. Chemistry of Carboxylic Acid. $1^{\text {st }}$ Ed. Publisher Research World, Delhi. 2012.

22. Purba J, Situmorang M. Inovasi Pembelajaran Berbasis Proyek Untuk Meningkatkan Kompetensi Mahasiswa Pada Pengajaran Gugus Fungsi [Innovation of Project Based Learning to Improve Students Competecies on the Teaching of Functional Group], Prosiding Seminar Nasional dan Rapat Tahunan BKS PTN-B, Universitas Tanjungpura Pontianak Indonesia. 2015;506-13.
23. Simaremare S, Situmorang M, Tarigan S. Innovative Learning Material with Project to Improve Students Achievement on the Teaching of AcidBase Equilibrium, Advances in Social Science. Education and Humanities Research, $3^{\text {rd }}$ Annual International Seminar on Transformative Education and Educational Leadership. 2018;200:431-6.

24. UNIMED. Universitas Negeri Medan, Kurikulum Berorientasi Kerangka Kualifikasi Nasional Indonesia (KKNI). UNIMED Medan, Indonesia. 2016.

25. Situmorang M, Sinaga M, Purba J, Daulay SI, Simorangkir M, Sitorus M, et al. Implementation of Innovative Chemistry Learning Material With Guided Tasks to Improve Students' Competence. J Balt Sci Educ. 2018;17(4):535-50.

26. Pedersen SF, Myers AF. Understanding The Principle of Organic Chemistry, A Laboratory Course. 2011. Brooks/Cole, Cengage Learning, Belmont, USA.

27. Gilbert JC, Martin SF. Experimental Organic Chemistry, A Miniscale and Microscale Approach. 2011. $5^{\text {th }}$ ed., Brooks/Cole, Cengage Learning, Belmont, USA.

28. Situmorang $M$, Sitorus $M$, Hutabarat W, Situmorang Z. The Development of Innovative Chemistry Learning Material for Bilingual Senior High School Students in Indonesia. International Educational Studies. 2015;8(10):72-85.

29. Solomons TWG, Fryhle CB, Snyder SA. Organic Chemistry. 2014. John Wiley and Sons, Inc. USA.

30. Carey FA, Giuliano RM. Organic Chemistry. 2011. $8^{\text {th }}$ ed McGraw-Hill, New York.

31. Tojo G, Fernández M. Oxidation of Primary Alcohols to Carboxylic Acids A Guide to Current Common Practice. Springer Science+Business Media, LLC, New York. 2007.

32. Sutiani A, Silalahi A, Situmorang M. The Development of Innovative Learning Material With Problem Based Approach to Improve Students Competence in The Teaching of Physical Chemistry. Advances in Social Science. Education and Humanities Research, $3^{\text {rd }}$ Annual International Seminar on Transformative Education and Educational Leadership. 2017;104:378-82.

33. Tan JCL, Chapman A. Project-Based Learning for Academically-Able Student. Sense Publishers, Rotherdam, The Netherlands. 2016.

34. Alrefaie Z, Eldeek B, Ayuob N. Effect of integrating research skills with basic sciences in an interdisciplinary integrated endocrine module on students' satisfaction and performance. Indian J Pharm Educ Res. 2017;51(1):14-9.

35. Tan JCL, Chapman A. Project-Based Learning for Academically-Able Student. Sense Publishers, Rotherdam, The Netherlands. 2016.

36. Straub J, Marsh RA, Whalen DJ. Small Spacecraft Development Project-Based Learning Implementation and Assessment of an Academic Program. Springer International Publishing, Switzerland. 2017. DOI 10.1007/978-3-319-23645-2.

37. Krauss J, Boss S. Thinking Through Project-Based Learning Guiding Deeper Inquiry, Corwin, a Sage Co, California. 2013.

38. Can B, Yıldız-Demirtaş V. Altun E. The Effect of Project-Based Science Education Programme on Scientific Process Skills and Conceptions of Kindergarten Students. J Balt Sci Educ. 2017;16(3):395-413.

39. Thompson KJ, Beak J. The Leadership Book: Enhancing the TheoryPractice Connection Through Project Based Learning. J. Manag. Educ. 2007;31(2):278-91.

40. Ofstad W, Brunner LJ. Team-Based Learning in Pharmacy Education. Am J Pharm Educ. 2013;77(4):1-11.

41. Gubacs K. Project-based Learning: A Student-centered Approach to Integrating technology into Physical Education Teacher Education. J Phys Educ Recreat Dance. 2004;75(7):33-43.

42. Behizadeh N. Enacting Problem Posing Education through Project-Based Learning. Engl J. 2014;104(2):99-104.

43. Hodges HF, Massey AT. Interprofessional Problem-Based Learning Project Outcomes Between Prelicensure Baccalaureate of Science in Nursing and Doctor of Pharmacy Programs. J Nurs Educ. 2015;54(4):201-6.

44. Ansari MT, Rahman SA, Badgujar VB, Sami F, Abdullah, MS. Problem Based Learning (PBL): A Novel and Effective Tool of Teaching and Learning. Indian J Pharm Educ Res. 2015;49(4):258-65. 


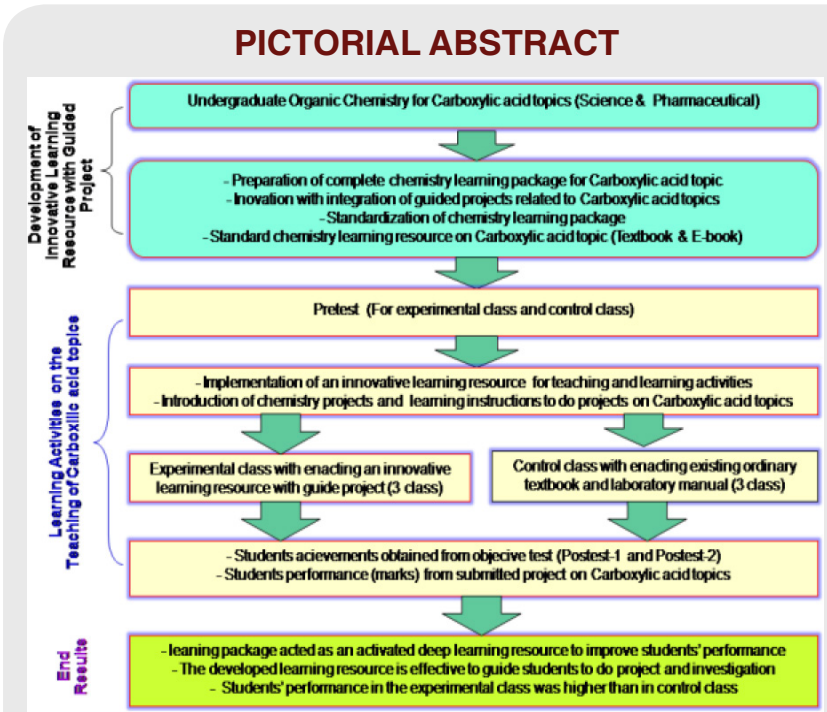

About Authors

\section{SUMMARY}

An innovative learning resources with guided project in line with current technology has been developed for undergraduate chemistry and pharmacy students. This develpment was carried out by enhanching the learning material with relevant contextual project examples on carboxylic acid topic, integration of learning media, the hyperlink to a trust website, problem solving and evaluation test. The learning resource has been used to guide the students to do project with target target goal to improve students' skills to do investigation and to handle chemical reaction. The results revealed that the developed leaning package acted as an activated deep learning resource to improve students' performance on Organic Chemistry. The guided projects integrated in the learning material has transformed student activity to become an enjoyable learning and the target goals are achieved. Students learning outcomes in experimental class is found higher than that obtained in control class.

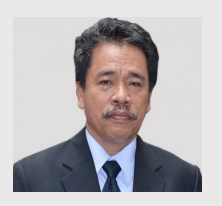

Professor Manihar Situmorang: was born on 4 August 1960. He is a Professor at Department of Chemistry, Faculty of Mathematics and Natural Sciences, Universitas Negeri Medan, Medan, North Sumatra, INDONESIA. He has been teaching for more than 32 years. He was graduated from Dept. of Chemistry Education at Institute of Teacher Training Education Medan, INDONESIA (B.Sc. 1986), and from Dept. of Chemistry, The University of New South Wales (UNSW), Australia (Grad. Diploma 1989, M.Sc, 1992 and Ph.D, 2001). He is currently a Vice Rector on Planning, Collaboration and Communication Affairs at Universitas Negeri Medan, was a Dean in Faculty of Mathematic and Natural Sciences for 8 years, and Head of Research Institute for 4 years. His research interests are on Sensor Development, Electroanalysis, Environmental Study and Chemistry Education.

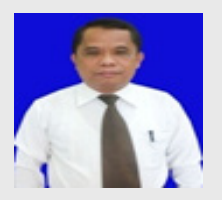

Professor Ramlan Silaban: was born on 18 June 1960. He is a Professor at Department of Chemistry, Faculty of Mathematics and Natural Science Universitas Negeri Medan, Medan, North Sumatera, INDONESIA. He was graduated from Dept. of Chemistry Education at Institute of Teacher Training Education Medan, INDONESIA (B.Sc. 1991), Master in Chemistry (M.Sc, 1991) and Doctor in Biochemistry (Dr, 1999) from Bandung Institute of Technology (ITB), Bandung, INDONESIA. He hold a position as Head of Chemistry Education, Graduate Study Program, Universitas Negeri Medan (2006-2019). His research interests are on Biochemistry and Chemistry Education.

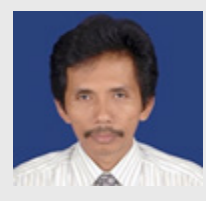

Jamalum Purba: was born on 16 February 1964. He is currently a Ph.D student at Chemistry Education, Graduate Study Program, Universitas Negeri Medan, Medan, North Sumatra, INDONESIA. He was graduated from Dept. of Chemistry Education at Institute of Teacher Training Education, Medan, INDONESIA (B.Sc. 1987), Dept. of Chemistry, Universitas Gajah Mada (M.Sc. 2001). He holds a position as a Lecturer in the Department of Chemistry Education, Universitas Negeri Medan since 1991. His research interests are on Organic Chemistry and Chemistry Education.

Cite this article: Purba J, Situmorang M, Silaban R. The Development and Implementation of Innovative Learning Resource with Guided Projects for the Teaching of Carboxylic Acid Topic. Indian J of Pharmaceutical Education and Research. 2019;53(4):603-12. 